\title{
KEEFEKTIFAN MEDIA VIDEO TUTORIAL TERHADAP \\ PENINGKATAN KETERAMPILAN MENULIS TEKS \\ PROSEDUR SISWA KELAS VI SDN 143 INPRES LEKO
}

\author{
Muhammad Amin ${ }^{1}$ \\ Abdul Rahman Rahim ${ }^{2 *}$ \\ Muhammad Akhir ${ }^{3}$ \\ ${ }^{1}$ SDN 143 Inpres Leko, Indonesia \\ 2,3Universitas Muhammadiyah Makassar, Makassar Indonesia \\ $\frac{\underbrace{1)}_{\text {muh.amin675@yahoo.com }}}{\text { rahman@unismuh.ac.id }^{2 *}}$
}

\begin{abstract}
Abstrak
Tujuan penelitian ini adalah untuk memperoleh, menganalisis, menginterpretasi dan menyajikan, serta melaporkan data mengenai keefektifan media video tutorial dalam meningkatkan keterampilan menulis teks prosedur siswa kelas VI SDN 143 Inpres Leko Kecamatan Moncongloe Kabupaten Maros. Jenis penelitian ini adalah penelitian eksperimen semu. Adapun populasi penelitian adalah seluruh siswa kelas VI SDN 143 Inpres Leko Kecamatan Moncongloe Kabupaten Maros tahun pelajaran 2020/2021. Populasi tersebut berjumlah 29 orang yang dengan teknik pengambilan sampel adalah total sampling. Hasil penelitian ini menunjukkan bahwa (1) Tingkat Keterampilan Menulis Teks Prosedur siswa kelas VI SDN 143 Inpres Leko Kecamatan Moncongloe Kabupaten Maros sebelum menggunakan media video tutorial berada pada kategori sedang (2) Tingkat Keterampilan Menulis Teks Prosedur siswa kelas VI SDN 143 Inpres Leko Kecamatan Moncongloe Kabupaten Maros setelah menggunakan media video tutorial berada pada kategori tingggi (3) Media video tutorial efektif dalam pembelajaran menulis teks prosedur siswa SD terutama bagi siswa kelas VI SDN 143 Inpres Leko Kecamatan Moncongloe Kabupaten Maros. Hal ini telah dibuktikan dalam hasil penelitian yang menunjukkan bahwa terdapat perbedaan yang signifikan antara tingkat keterampilan menulis teks prosedur siswa sebelum dan sesudah menggunakan media video tutorial.
\end{abstract}

Kata Kunci: Keefektifan, Media Video Tutorial, Keterampilan Menulis, Teks Prosedural

Published by:

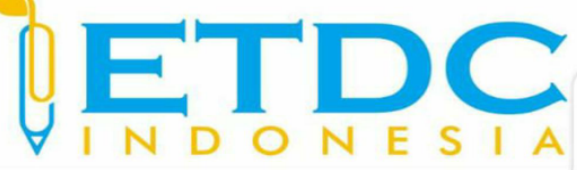

Copyright (C) 2021 The Author (s)

This article is licensed under CC BY 4.0 License

\section{(cc) $\mathrm{BY}$}




\section{KEEFEKTIFAN MEDIA VIDEO TUTORIAL TERHADAP PENINGKATAN KETERAMPILAN MENULIS TEKS PROSEDUR SISWA KELAS VI SDN 143 INPRES LEKO}

\section{Pendahuluan}

Dalam kehidupan modern ini, keterampilan menulis sangat dibutuhkan. Tidak berlebihan bila dikatakan menulis merupakan ciri dari orang yang terpelajar atau bangsa yang terpelajar. Sehubungan dengan hal ini Tarigan (1985) menyatakan bahwa: "Menulis digunakan oleh seseorang yang terpelajar untuk mencatat, menyakinkan, melaporkan, serta memengaruhi orang lain. Tujuan seperti itu hanya dapat dicapai oleh orang yang dapat menyusun buah pikiran dan mengutarakannya dengan jelas. Kejelasan ini tergantung pada pikiran, organisasi, pemakaian kata-kata, dan struktur kalimat yang tersusun dengan baik. Keterampilan menulis merupakan modal dalam kehidupan seseorang, baik di sekolah, di kampus maupun di luar sekolah/kampus. Keterampilan menulis sebagai suatu bentuk komunikasi secara tertulis dapat dikatakan sebagai suatu kebutuhan bagi setiap orang utamanya para siswa. Keterampilan menulis yang memadai khususnya dalam karang-mengarang tidak akan diperoleh tanpa menguasai berbagai keterampilan yaitu keterampilan memilih kata yang tepat, membuat kalimat, keterampilan menggunakan ejaan, dan sebagainya.

Minimal ada tiga komponen yang tergabung dalam perbuatan menulis, yaitu : (1) penguasaan bahasa tulis, yang akan berfungsi sebagai media tulisan, meliputi : kosakata, struktur kalimat, paragraf, ejaan, pragmatik, dan sebagainya; (2) penguasaan isi karangan sesuai dengan topik yang akan ditulis; dan (3) penguasaan tentang jenis-jenis tulisan, yaitu cara merangkai isi tulisan dengan menggunakan bahasa tulis sehingga membentuk sebuah komposisi yang diinginkan, seperti esai, artikel, cerita pendek, makalah, karangan dan sebagainya (Kurniawan, 2013).

Banyak hasil penelitian menunjukkan hal tersebut. Penelitian tentang ketidakmampuan siswa dalam menulis karangan ditunjukkan oleh Arviyana, Syahrul, dan Tressyalina (2017). Hasil penelitiannya mengungkapkan bahwa kendala yang ditemukan pada siswa dalam menulis terdapat pada indikator, yaitu struktur, diksi, ciri kebahasaan, dan EBI (Ejaan Bahasa Indonesia). Penelitian tentang keterampilan menulis juga dilakukan Azura dan Syamsul (2017). Hasilnya penelitiannya juga mengungkapkan bahwa keterampilan menulis masih mengalami kendala, yakni kurangnya motivasi dan minat siswa dalam membaca, keterampilan menulis siswa berdasarkan aspek struktur teks, ciri kebahasaan, dan Ejaan Bahasa Indonesia khususnya penggunaan huruf kapital dan tanda baca. 
Untuk itu upaya mengembangkan keterampilan menulis siswa melalui berbagai cara termasuk secara sistematis dalam bentuk penelitian harus terus dilakukan. Salah satu jenis menulis yang tidak lepas dari persoalan di atas adalah menulis teks prosedur. Teks prosedur penting dikuasai siswa karena sangat berguna untuk melengkapi aktivitas tertentu pada kehidupan sehari-hari kelak, seperti membuat resep, membuat petunjuk penggunaan, perakitan, dan sebagainya.

Salah satu pembelajaran Bahasa Indonesia yang menuntut guru untuk menggunakan media ajar yang kreatif adalah pembelajaran teks prosedur. Prosedur merupakan teks yang menjelaskan langkah-langkah secara lengkap dan jelas tentang cara melakukan sesuatu (Rusman, 2013). Pembelajaran mengenai teks prosedur sangat penting untuk dipelajari oleh siswa, karena dengan adanya pembelajaran teks prosedur dapat menambah pengetahuan dan wawasan siswa tentang langkah-langka atau tahapan-tahapan yang harus ditempuh sebelum melakukan sesuatu. Dengan adanya pembelajaran teks prosedur siswa juga tahu apa yang harus dilakukan sebelum melakukan sesuatu yang ingin dikerjakan sehingga siswa tidak ragu-ragu dalam melakukan suatu yang akan dilakukan. Media pembelajaran yang cocok dengan pembelajaran teks prosedur adalah video tutorial.

Menurut Riyana (2017) media video pembelajaran adalah media yang menyajikan audio dan visual yang berisi pesan-pesan pembelajaran baik yang berisi konsep, prinsip, prosedur, teori, aplikasi untuk membantu pemahaman terhadap suatu materi pembelajaran. Menurut Susilana dan Riyana (2017) model tutorial adalah pembelajaran melalui komputer dimana siswa dikondisikan untuk mengikuti alur pembelajaran yang sudah terprogram dengan penyajian materi dan latihan soal. Pendapat di atas dapat disimpulkan bahwa video tutorial adalah media pembelajaran yang menyampaikan pesan kepada siswa berupa audio dan visual yang didalamnya terdapat materi pembelajaran interaktif sehingga siswa dapat belajar secara mandiri yang tidak dibatasi dengan tempat.

Berdasarkan kenyataan di atas, penulis terdorong untuk melakukan penelitian berkaitan dengan upaya meningkatkan keterampilan menulis siswa dengan menyodorkan strategi pembelajaran menulis yang kreatif dalam bentuk media pembelajaran. Adapun penelitian yang dimaksud adalah ujicoba media video tutorial dalam meningkatkan keterampilan menulis teks prosedural siswa kelas VI SDN 143 Inpres Leko Kecamatan Moncongloe Kabupaten Maros. Penelitian ini diharapkan dapat mengubah secara langsung keterampilan siswa selain menghasil konsep dan strategi pembelajaran yang dapat dimanfaatkan guru lain dalam meningkatkan keterampilan menulis siswa khususnya teks prosedural. 


\section{Tinjauan Teoritis}

Kualitas pengajaran bahasa dan sastra sejauh ini sering dipertanyakan dan diragukan. Berdasarkan fakta empirik yang ditemukan Sukoco (2011:115) penyebab dari hal itu adalah metodologi pengajaran bahasa dan sastra yang tidak efisien. Kualitas pembelajaran bahasa dan sastra masih sangat memprihatinkan diindikasikan oleh pengajaran bahasa dan sastra yang seadanya. Penelitian mengenai masalah pembelajaran bahasa dan sastra cukup banyak dilakukan, meskipun tidak rinci mengenai problematiknya. Alwi (2011) mengemukakan bahwa problem klasik yang selama ini menggangu semangat belajar siswa seperti (1) keseragaman kurikulum, (2) pembelajaran yang berpusat pada guru, (3) beban administrasi guru yang tinggi, dan (4) jumlah siswa dalam satu kelas terlalu besar perlu dicarikan solusi. Hal senada dikemukakan oleh Simaremare (2012) mengemukakan bahwa problematika pengajaran bahasa dan sastra yang terjadi sekarang ini disebabkan oleh berbagai faktor sehingga penanganannya mesti dilakukan secara holistik, tidak bisa parsial. Demikian halnya Rizaldi (2012) menyatakan dalam penelitiannya bahwa pembelajaran sastra mengalami masalah terutama masalah guru yang minat dan komptensi sastranya belum memadai. Simaremare (2012) bahwa pembelajaran bahasa dan sastra di SD harus memberi pengalaman pada murid yang akan berkontribusi pada empat tujuan (1) menumbuhkan kesenangan pada buku, (2) menginterpretasi bacaan bahasa dan sastra (3) mengembangkan kesadaran bersastra, dan (4) mengembangkan apresiasi.

Muslimin (2013) menyatakan bahwa dalam pengajaran sastra, "siswa hendaknya membaca lebih banyak buku dengan rasa puas. menyatakan bahwa terdapat tiga tahap urutan dan perkembangan yang ada dalam pertumbuhan apresiasi (1) tahap kenikmatan yang tidak sadar, (2) tahap apresiasi yang masih ragu-ragu atau berada antara tahap kesatu dan ketiga, dan (3) tahap kegembiraan secara sadar.

Nurgiantoro (2011:319) menyatakan bahwa penggabungan bahasa dan sastra ke dalam pembelajaran bahasa Indonesia memang wajar dan dapat dimengerti. Sebab, bahasa merupakan sarana pengucapan sastra, bahasa merupakan salah satu unsur bentuk bahasa dan sastra yang sangat penting. Bahkan secara lahiriah, aspek formal yang tampak, wujud bahasa dan sastra adalah bahasa. Natia (2014:1) mengatakan menulis adalah suatu proses kegiatan pikiran seseorang yang hendak mengungkapkan buah pikiran dan perasaannya kepada orang lain atau kepada dirinya sendiri dalam bentuk tulisan. Menulis merupakan bentuk komunikasi untuk menyampaikan gagasan penulis kepada khalayak/pembaca yang dibatasi oleh jarak tempat, dan waktu (Akhdiah dkk., 2011).

Teks prosedur/arahan merupakan jenis teks yang termasuk genre faktual, subgenre prosedural. Menurut Mahsun (2018), “Tujuan sosial teks ini adalah mengarahkan atau 
mengajarkan tentang langkah-langkah yang telah di tentukan.” Jenis teks ini lebih menekankan pada aspek bagaimana melakukan sesuatu, yang dapat berupa salah satunya percobaan atau pengamatan. Sardiman (2011) mengemukakan bahwa media pembelajaran adalah teknologi pembawa pesan yang dapat dimanfaatkan untuk keperluan pembelajaran. Syaidiman (2018) mengungkapkan bahwa media pembelajaran yang digunakan dalam kegiatan pembelajaran dapat mempengaruhi terhadap efektivitas pembelajaran.

Untuk memperjelas pengertian di atas dikemukakan batasan media pembelajaran dari berbagai referensi. Syafiie dan Machfudz (2012); Sulaiman (1995); Rudi (2017); Abidin (2011: 2); Rudi (20170 mengemukakan pengertian media pembelajaran "Media pembelajaran adalah perangkat lunak dan perangkat keras yang berfungsi sebagai alat belajar dan alat bantu belajar."

Di antara media pendidikan, media video adalah media yang paling efektif dipakai, karena merupakan bahasa yang umum dapat dimengerti dan dinikmati dimana-mana di era digital saat ini, sebuah video berbicara lebih banyak dari pada seribu kata. Video dapat mempformulasikan fakta secara detail selain meperlihahatkan proses sesuai baik bunyi maupun gambar.

Kelebihan media video adalah; (1) Sifatnya konkrit; (2) Video dapat mengatasi keterbatasan ruang dan waktu; (3) dapat mengatasi keterbatasan pengamatan; (4) Dapat memperjelas suatu masalah dalam bidang apa saja dan (5) dapat dibuat denga muda pada era digital saat ini dengan murah serta menggunakannya; (5) dapat mendetailkan objek baik gambar maupun suara (Rudi (2017:15). Keunggulan penggunaan media video dalam pembelajaran juga dikemukakan Hasan (2013); Sucahyono dan Haryono, (2018.) Informasi yang dimiliki seseorang diperoleh melalui penglihatan sebanyak $83 \%$, melalui pendengaran $11 \%$, penciuman $3,5 \%$, perabaan $1,5 \%$ dan rasa $1 \%$, sehingga perpanduan pandang dengar $94 \%$.

Penelitian ini berusaha mengungkap keefektifan media video tutorial dalam meningkatkan keterampilan menulis teks prosedur siswa kelas VI SDN 143 Inpres Leko Kecamatan Moncongloe Kabupaten Maros. Penelitian ini diharapkan dapat menjadi masukan dalam upaya meningkatkan keterampilan menulis teks prosedur peserta didik di sekolah dasar.

\section{Metode Penelitian}

Jenis penelitian yang digunakan adalah penelitian eksperimen semu (quasi experimental) yaitu penelitian eksperimen yang dilaksanakan pada satu kelompok saja yang dinamakan kelompok eksperimen tanpa ada kelompok pembanding atau kelompok control. Desain penelitian yang digunakan adalah one group pretest-posttest design, yaitu penelitian eksperimen yang dilaksanakan pada satu kelompok saja. Desain penelitian one group pretest 
and posttest design ini diukur dengan menggunakan pretest yang dilakukan sebelum diberi perlakuan dan posttest yang dilakukan setelah diberi perlakuan untuk setiap pembelajaran. Penelitian ini berlokasi di SD Negeri 143 Inpres Leko Kabupaten Maros, Provinsi Sulawesi Selatan dengan peserta didiki kelas VI SDN 143 Inpres Leko Kabupaten Maros tahun pelajaran 2020/2021 sejumlah 29 orang yang sekaligus juga sebagai objek penelitian. Data dalam penelitian ini merupakan data kuantitatif jenis skala, berupa skor-skor hasil tes/pengukuran keterampilan menulis teks prosedur peserta didik yang menjadi objek penelitian.

Pengumpulan data dalam penelitian ini dilakukan teknik tes (pengetesan hasil belajar) berupa tes hasil belajar menulis teks prosedur. Data Hasil belajar menulis teks prosedur siswa baik sebelum maupun sesudah menggunakan media video tutorial dianalisis dengan teknik presentasi (\%) dengan rumus :

$$
\mathrm{S}=\frac{\mathrm{n}}{\mathrm{N}} \mathrm{X} 100 \text { untuk rentang 10-100. }
$$

Untuk melihat keefektifan media video tutorial dalam pembelajaran menulis teks prosedur siswa kelas VI SDN 143 Inpres Leko Kecamatan Moncongloe Kabupaten Maros adalah perhitungan statistik inferensial dengan Analisis computer fasilitas uji t Data Analysis pada Paired-Sample T-Test pada program exel. Analisis data di atas dikonversi ke dalam tabel signifikan 5\%

\section{Hasil dan Pembahasan}

\section{a. Hasil Penelitian}

1. Tingkat keterampilan menulis teks prosedur siswa kelas VI SDN 143 Inpres Leko Kecamatan Moncongloe Kabupaten Maros sebelum menggunakan media video tutorial Data tingkat keterampilan menulis teks prosedur siswa kelas VI SDN 143 Inpres Leko Kecamatan Moncongloe Kabupaten Maros sebelum menggunakan media video tutorial media video tutorial dapat dilihat pada ringkasan nilai konversi 1-100 dari skor mentah dapat dilihat pada Tabel 1 berikut.

Tabel 1. Statistik nilai keterampilan menulis teks prosedur siswa kelas VI SDN 143 Inpres Leko Kecamatan Moncongloe Kabupaten Maros sebelum menggunakan media video tutorial.

\begin{tabular}{cc}
\hline Statistik & Nilai Statistik \\
\hline Subjek & 29 \\
Nilai Ideal & 100 \\
Nilai Tertinggi & 75,56 \\
Nilai Terendah & 51,11 \\
Nilai Rata-rata & 60,46 \\
\hline
\end{tabular}


Tabel 1 menunjukkan bahwa nilai rata-rata keterampilan menulis teks prosedur siswa kelas VI SDN 143 Inpres Leko Kecamatan Moncongloe Kabupaten Maros sebelum menggunakan media video tutorial dengan subjek/responden penelitian 29 orang siswa sebesar 60,46. Nilai yang dicapai responden tersebar dengan nilai tertinggi 75,56 dan nilai terendah 51.11 dari nilai tertinggi yang mungkin dicapai 100 dan nilai terendah yang mungkin dicapai 0. Berdasarkan kategorisasi, maka dinyatakan bahwa nilai keterampilan menulis teks prosedur siswa kelas VI SDN 143 Inpres Leko Kecamatan Moncongloe Kabupaten Maros sebelum menggunakan media video tutorial berada pada kategori sedang.

2. Tingkat keterampilan menulis teks prosedur siswa kelas VI SDN 143 Inpres Leko Kecamatan Moncongloe Kabupaten Maros sesudah menggunakan media video tutorial

Data tingkat keterampilan menulis teks prosedur siswa kelas VI SDN 143 Inpres Leko Kecamatan Moncongloe Kabupaten Maros sesudah menggunakan media video tutorial media video tutorial dapat dilihat pada ringkasan nilai konversi 1-100 dari skor mentah dapat dilihat pada Tabel 2 berikut.

Tabel 2. Statistik nilai keterampilan menulis teks prosedur siswa kelas VI SDN 143 Inpres Leko Kecamatan Moncongloe Kabupaten Maros sesudah menggunakan media video tutorial.

\begin{tabular}{cc}
\hline Statistik & Nilai Statistik \\
\hline Subjek & 29 \\
Nilai Ideal & 100 \\
Nilai Tertinggi & 84,44 \\
Nilai Terendah & 64,44 \\
Nilai Rata-rata & 71,95 \\
\hline
\end{tabular}

Tabel 2 menunjukkan bahwa nilai rata-rata keterampilan menulis teks prosedur siswa kelas VI SDN 143 Inpres Leko Kecamatan Moncongloe Kabupaten Maros sesudah menggunakan media video tutorial dengan subjek/responden penelitian 29 orang siswa sebesar 71,95. Nilai yang dicapai responden tersebar dengan nilai tertinggi 84,44 dan nilai terendah 64,44 dari nilai tertinggi yang mungkin dicapai 100 dan nilai terendah yang mungkin dicapai 0. Berdasarkan kategorisasi, maka dinyatakan bahwa nilai keterampilan menulis teks prosedur siswa kelas VI SDN 143 Inpres Leko Kecamatan Moncongloe Kabupaten Maros sesudah menggunakan media video tutorial berada pada kategori tinggi.

3. Keefektifan media video tutorial dalam pembelajaran menulis teks prosedur siswa kelas VI SDN 143 Inpres Leko Kecamatan Moncongloe Kabupaten Maros (Analisis Uji-T/pengujian hipotesis) 
Untuk menentukan keefektifan media video tutorial dalam pembelajaran menulis teks prosedur siswa kelas VI SDN 143 Inpres Leko Kecamatan Moncongloe Kabupaten Maros maka data dari sebelum dan sesudah penerapan menggunakan media video tutorial dianalisis dengan menggunakan komputer fasilitas uji t Data Analysis pada Paired-Sample T-Test pada program exel.

Secara deskriptif kedua data tersebut dapat diringkas sebagai berikut (Lihat Tabel 3).

Tabel 3. T-Test: Paired Two Sample for Means

\begin{tabular}{lrr}
\hline & Variable 1 & Variable 2 \\
\hline Mean & 60,45977 & 71,95402 \\
Variance & 41,40364 & 39,65213 \\
Observations & 29 & 29 \\
Pearson Correlation & 0,734415 & \\
Hypothesized Mean & & \\
Difference & 0 & \\
$\mathrm{t}$ Stat & 28 & \\
$\mathrm{P}(\mathrm{T}<=\mathrm{t})$ one-tail & 13,3366 & \\
$\mathrm{t}$ Critical one-tail & $5,93 \mathrm{E}-14$ & \\
$\mathrm{P}(\mathrm{T}<=\mathrm{t})$ two-tail & 1,701131 & \\
$\mathrm{t}$ Critical two-tail & $\mathbf{1 , 1 9 E - 1 3}$ & \\
\hline
\end{tabular}

4. Pengujian hipotesis

Berdasarkan hasil pengolahan dan penyajian data, maka dapat dipaparkan pengujian hipotesis bahwa hasil analisis data diperoleh nilai " $t$ " stat adalah 13,336 sedangkan nilai t Critical two-tail adalah 2,048407 maka dapat dijelaskan nilai stat lebih besar daripada nilai t Critical two-tail (stat:13,336> t Critical two-tail: 2,048407) pada taraf signifikan 0,05. Atau dapat juga dilihat pada nilai $\mathrm{P}(\mathrm{T}<=\mathrm{t})$ two-tail sama dengan 1,19 dan nilai signifikansi 0,05, maka dapat dijelaskan nilai $\mathrm{P}(\mathrm{T}<=\mathrm{t})$ two-tail lebih besar daripada nilai signifikansi $(\mathrm{P}(\mathrm{T}<=\mathrm{t})$ two-tail:1,19>0,05). Hal menunjukkan bahwa hipotesis nol yang berbunyi: "Media video tutorial tidak efektif meningkatkan keterampilan menulis teks prosedur siswa kelas VI SDN 143 Inpres Leko Kecamatan Moncongloe Kabupaten Maros ditolak. Hipotesis alternatif berbunyi "Media video tutorial efektif dalam pembelajaran menulis teks prosedur siswa kelas VI SDN 143 Inpres Leko Kecamatan Moncongloe Kabupaten Maros" diterima. Dengan demikian, dapat dikemukakan bahwa media video tutorial efektif meningkatkan keterampilan menulis teks prosedur siswa kelas VI SDN 143 Inpres Leko Kecamatan Moncongloe 
Kabupaten Maros pada taraf kepercayaan 95\%.

\section{b. Pembahasan}

Berdasarkan hasil penelitian ini dapat dipahami bahwa untuk mengefektifkan pembelajaran menulis teks prosedur khususnya siswa sekolah dasar, salah satu metode pembelajaran yang baik untuk digunakan adalah media video tutorial. Hal ini telah dibuktikan dengan ujicoba keefektifannya yang menunjukkan efektif. Secara rasional media video tutorial dapat membantu siswa dalam membangun kosep teks yang harus dituilis. Selain itu, dapat memberi pengalaman langsung kepada siswa dalam mencermati hakikat yang akan ditulis secara prosedural.

Pengajaran menulis termasuk teks prosedur yang selama ini dianggap kurang diminati siswa atau sulit, dapat dilatihkan dengan menggunakan media video tutorial untuk merangsang daya imajinasi siswa dalam menulis juga memberi daya tarik dalam pembelajaran.

Pemanfaatan video tutorial dalam penelitian terdapat beberapa keunggulan antara lain (1) secara tidak langsung terjadi proses pembelajaran bidang studi lain dan pembahasan aspek pembelajaran bahasa Indonesia lainnya secara terencana dan sistematis (lintas bidang studi dan lintas unit/aspek pembelajaran bahasa); (2) dapat memupuk keberanian, sikap ilmiah, pikiran kritis siswa; (3) dapat menimbulkan dampak pengiring yang positif seperti; belajar diskusi, menyimak, dan sebagainya.

Hasil penelitian ini sesuai dengan konsep yang dikemukakan oleh Rudi (2017:15) bahwa kelebihan media video adalah; (1) Sifatnya konkrit, lebih realistis dibandingkan media verbal; (2) Video dapat mengatasi keterbatasan ruang dan waktu; (3) Video dapat mengatasi keterbatasan pengamatan termasuk gerak; (4) Dapat memperjelas suatu masalah dalam bidang apa saja dan usia berapa saja; dan (5) Murah dan mudah membuat dan menggunakannya di era digital sekarang ini. De Porter (2013) mengemukakan bahwa menggunakan imajinasi dari rangsangan gambar atau video, maka peserta didik mampu mengubah kalimat-kalimat yang kering menjadi deskripsi yang menakjubkan sebagai pemikiran brilian.

Demikian hal Harun (2013) menjelaskan bahwa gaya belajar audio visual siswa sangat dominan karena menggunakan hampir seluruh unsur seperti mencermati, menyimak, mengamati, membaca, menganalisis dan menyimpulkan objek yang dipelajari.

\section{Kesimpulan}

Berdasarkan hasil analisi dan pembahasan maka dapat disimpulkan bahwa, tingkat kemampuan menulis teks prosedur siswa kelas VI SDN 143 Inpres Leko Kecamatan 
Moncongloe Kabupaten Maros sebelum menggunakan media video tutorial berada pada kategori sedang dengan rerata $60,46 \%$ dan setelah menggunakan media video tutorial berada pada kategori tinggi dengan rerata 71,95\%. Media video tutorial efektif dalam pembelajaran menulis teks prosedur siswa SD terutama bagi siswa kelas VI SDN 143 Inpres Leko Kecamatan Moncongloe Kabupaten Maros. Hal ini telah dibuktikan dalam hasil penelitian yang menunjukkan bahwa terdapat perbedaan yang signifikan antara tingkat kleterampilan menulis teks prosedur siswa sebelum dan sesudah menggunakan media video tutorial.

\section{DAFTAR PUSTAKA}

Akhdiah, dkk. (2011) .Pembelajaran bahasa dan Sastra Indonesia. Jakarta: Gramedia Pustaka utama.

Alfansyah, (2017). Pembelajaran Bahasa dan Sastra Indonesia di SD. Bandung: Angkasa

Alwi, (2011). Masalah-masalah Pembelajaran Sastra. Jakarta: Insan press

Amalia, F., Syahrul, R., \& Arief, E. (2018). Pengaruh Model Discovery Learning Berbantuan Media Audiovisual Terhadap Keterampilan Menulis Teks Eksposisi Siswa Kelas VIII SMP Negeri 31 Padang. Jurnal Pendidikan Bahasa dan Sastra Indonesia, 7(1), 125-132.

Arviyana, M., \& Syahrul, T. (2017). Pengaruh Model Discovery Learning Berbantuan Media Audiovisual terhadap Keterampilan Menulis Teks Prosedur Siswa Kelas VII SMP Negeri 12 Padang. Jurnal Pendidikan Bahasa dan Sastra Indonesia, 6(2).

Azura, A., \& Syamsul, A. (2017). Kemampuan menulis teks prosedur siswa kelas VII SMP Negeri 2 Percut Sei Tuan Tahun pembelajaran 2017/2018. Asas: Jurnal Sastra, 6(1).

Depdikbud 2013. Standar Isi. Jakarta: BNSP

De Porter, B., \& Hernachi, M. (2000). Quantum Learning: Membiasakan Belajar Nyaman dan Menyenangkan.(terjemahan Alwiyah Abdurrahman). Bandung: Kaifa..(2001). Quantum Learning: Membiasakan Belajar Nyaman dan Menyenangkan.

Fitri, R., Emidar, E., \& Rasyid, Y. (2018). PENGARUH MODEL DISCOVERY LEARNING BERBANTUAN MEDIA AUDIOVISUAL TERHADAP KETERAMPILAN MENULIS TEKS FABEL SISWA KELAS VII SMP NEGERI 7 PADANG. Jurnal Pendidikan Bahasa dan Sastra Indonesia, 7(3), 287-294.

Graves, D. H. (1983). Writing: Teachers and children at work. Heinemann Educational Books, 4 Front St., Exeter, NH 03833.

Haryono, (2018). Media Pembelajaran.Jakarta: Insan press

Hasan, A. (2013). Media Pembelajaran Konsep dan Strategi.Jakarta: Gema Media

Ibrahim, R. (2011) Penilaian Pembelajaran Sastra Surabaya: Kata Kita 
Machfudz. (2012). Media Pembelajaran Modern. Jakarta: Caya Insani Press

Mahsun. (2018). Ragam Teks. Bandung: Angkasa.

Muslimin. (2013). Pembelajaran Sastra di Sekolah. Bandung: mujahid Press

Nafiah. (2014). Anda Ingin Jadi Pengarang? Surabaya: Usaha Nasional.

Nefira, M. R., Basri, I., \& Emidar, E. (2019). Pengaruh Model Discovery Learning Berbantuan Media Audiovisual terhadap Keterampilan Menulis Teks Eksposisi Siswa Kelas VIII SMP Negeri 25 Padang. Jurnal Pendidikan Bahasa dan Sastra Indonesia, 8(1), 139-146.

Niswatuzzahro, V., Fakhriyah, F., \& Rahayu, R. (2018). Penerapan Model Discovery Learning Berbantuan Media Audio Visual untuk Meningkatkan Literasi Sains Siswa Kelas 5 SD. Scholaria: Jurnal Pendidikan dan Kebudayaan, 8(3), 273-284.

Nurgiantoro, Burhan. 2011. Penilaian dalam Pengajaran Bahasa dan Sastra. Yogyakarta: BPFE.

Putri, N., Syahrul, R., \& Afnita, A. (2018). PENGARUH PENGGUNAAN MODEL DISCOVERY LEARNING BERBANTUAN MEDIA AUDIOVISUAL TERHADAP KETERAMPILAN MENULIS TEKS BIOGRAFI SISWA KELAS X SMA NEGERI 12 PADANG. Jurnal Pendidikan Bahasa dan Sastra Indonesia, 7(3), 192-198.

Riyana, I. (2017). Seluk Beluk Pembelajaran Sastra. Jogjakarta: Analisa

Sardiman. (2011). Media Pembelajaran. Jakarta: Gema Press.

Simaremare. (2012). Problematika Pengajaran Bahasa dan Sastra. Medan: Membumi Publishing

Tarigan, H. G. (2013). Menulis sebagai Sebuah Keterampilan . Bandung: Angkasa

Wyatt \& Looper. (2010). Belajar dan Pembelajaran. Jakarta: Gramedia Pustaka Utama. 